\title{
24. BASALTS OF THE MIDDLE AMERICA TRENCH (GUATEMALA TRANSECT) AND THEIR CORRELATION WITH OCEANIC AND ISLAND-ARC THOLEIITES ${ }^{1}$
}

\author{
Yuri I. Dmitriev, Institute of Geology of Ore Deposits, Petrography, Mineralogy, \\ and Geochemistry of the U.S.S.R. Academy of Sciences, Moscow, U.S.S.R.
}

\begin{abstract}
During the Leg 67 drilling of the Middle America Trench (Guatemala transect), basalts were reached in Hole 495, 22 $\mathrm{km}$ seaward from the Trench axis, in Holes 500 and $500 \mathrm{~B}$ at the foot of the continental slope, and at four other holes not sampled for this study. Only olivine-plagioclase phyric basalts are present in Hole 495, whereas in Holes 500 and $500 \mathrm{~B}$ these rocks are associated with plagioclase phyric high-alumina basalts. As illustrated by the content of $\mathrm{TiO}_{2}$, $\mathrm{Al}_{2} \mathrm{O}_{3}$, and the $\mathrm{K}_{2} \mathrm{O} / \mathrm{K}_{2} \mathrm{O}+\mathrm{Na}_{2} \mathrm{O}$ ratio, some of the Middle America Trench basalts do not differ essentially from oceanic tholeiites, but others have a composition transitional to island-arc tholeiitic basalts. It is suggested that basalts transitional from oceanic to island-arc tholeiites are typical manifestations of magmatism in zones of convergence of the oceanic and continental or island-arc crust.
\end{abstract}

\section{INTRODUCTION}

In the Guatemala transect of the Middle America Trench, drilled during Leg 67, basalts were recovered in Holes 495, 500, and 500B (Fig. 1), and at four other holes hot sampled for this study.

Hole $495\left(12^{\circ} 29.78^{\prime} \mathrm{N}, 91^{\circ} 02.26^{\prime} \mathrm{W}\right)$ was drilled on the oceanic side of the Trench $22 \mathrm{~km}$ from its axis and 1295 meters above the floor of the Trench, on the horstlike ridge. The depth of the ocean at the site of drilling was 4140 meters. Basalts were reached under upper Miocene nannofossil-foraminiferal chalk, in the interval from 428.5 to 446.5 meters below the seafloor.

Hole $500\left(12^{\circ} 41.35^{\prime} \mathrm{N}, 90^{\circ} 56.49^{\prime} \mathrm{W}\right)$ was drilled in the Trench axis at the foot of the continental slope at a water depth of 6094 meters. Basalts, cored in the interval 156.5 to 165.5 meters below the seafloor, underlie upper Miocene nannofossil and foraminiferal sediments.

Hole 500B $\left(12^{\circ} 40.95^{\prime} \mathrm{N}, 90^{\circ} 56.62^{\prime} \mathrm{W}\right)$ was drilled at a water depth of 6090 meters and is also located in the Trench axis, but seaward from Hole 500 (see Site 500 report for location map). Basalts were recovered in the interval 115 to 133.5 meters below the seafloor, under Quaternary diatomaceous mud.

According to seismic reflection profiles, basalts located in the Guatemala transect of the Middle America Trench belong to the oceanic crust of the Cocos Lithospheric Plate, subducting under the continental Caribbean Plate (von Huene et al., 1980).

On the basis of petrographic and petrochemical peculiarities, basalts of the Middle America Trench (Guatemala transect) are subdivided into (1) olivine-plagioclase phyric normal basalts and (2) plagioclase phyric high-alumina basalts.

\footnotetext{
${ }^{1}$ Aubouin, J., von Huene, R., et al., Init. Repts. DSDP, 67: Washington (U.S. Govt. Printing Office).
}

\section{PETROGRAPHY OF BASALTS}

\section{Olivine-plagioclase Phyric Basalts}

According to available data, olivine-plagioclase phyric basalts are the only igneous rocks recovered in Hole 495; however, in Hole 500 they overlie plagioclase phyric basalts.

Olivine-plagioclase phyric basalts consist of a glassy or fine-grained matrix with small crystals of plagioclase, pyroxene, and ore minerals, as well as phenocrysts of plagioclase, olivine, and spinel. The content of phenocrysts changes from several grains to 7 to $8 \%$ (Table 1).

The texture of basalts is usually hyalopilitic or intersertal, sometimes with trachytic features caused by subparallel orientation of plagioclase microlaths. Vesicles comprise as much as $1.5 \%$ of the volume of the basalts and are filled with smectite and calcite.

Phenocrysts of the plagioclase are represented by bytownite $\mathrm{An}_{80-81}$ (Table 2), sometimes contain inclusions of Cr-spinel (Table 3), and form glomeroporphyric aggregates with phenocrysts of olivine-chrysolite $\mathrm{Fo}_{88-85}$ (Table 4). The abundance of plagioclase phenocrysts in olivine-plagioclase phyric basalts is rather constant and does not depend on the degree of their crystallization.

Experimental homogenization of melt inclusions in plagioclase phenocrysts from Sample 495-48-1, $83 \mathrm{~cm}$ indicated their crystallization at a temperature of about 1220 to $1250^{\circ} \mathrm{C}$ (analysis by I. P. Solovova, Institute of Geology of Ore Deposits, Petrography, Mineralogy, and Geochemistry of the U.S.S.R. Academy of Sciences, Moscow). Phenocrysts of spinel with the ratio $\mathrm{Cr} / \mathrm{Cr}+\mathrm{Al}=0.49$ were formed under nearly the same conditions, that is 1230 to $1250^{\circ} \mathrm{C}$ (Fist and Bence, 1980).

Among groundmass minerals, plagioclase microlites (bytownite, $\mathrm{An}_{76-70}$ are the most idiomorphic crystalline phase (Table 2). The content of plagioclase crystals in 


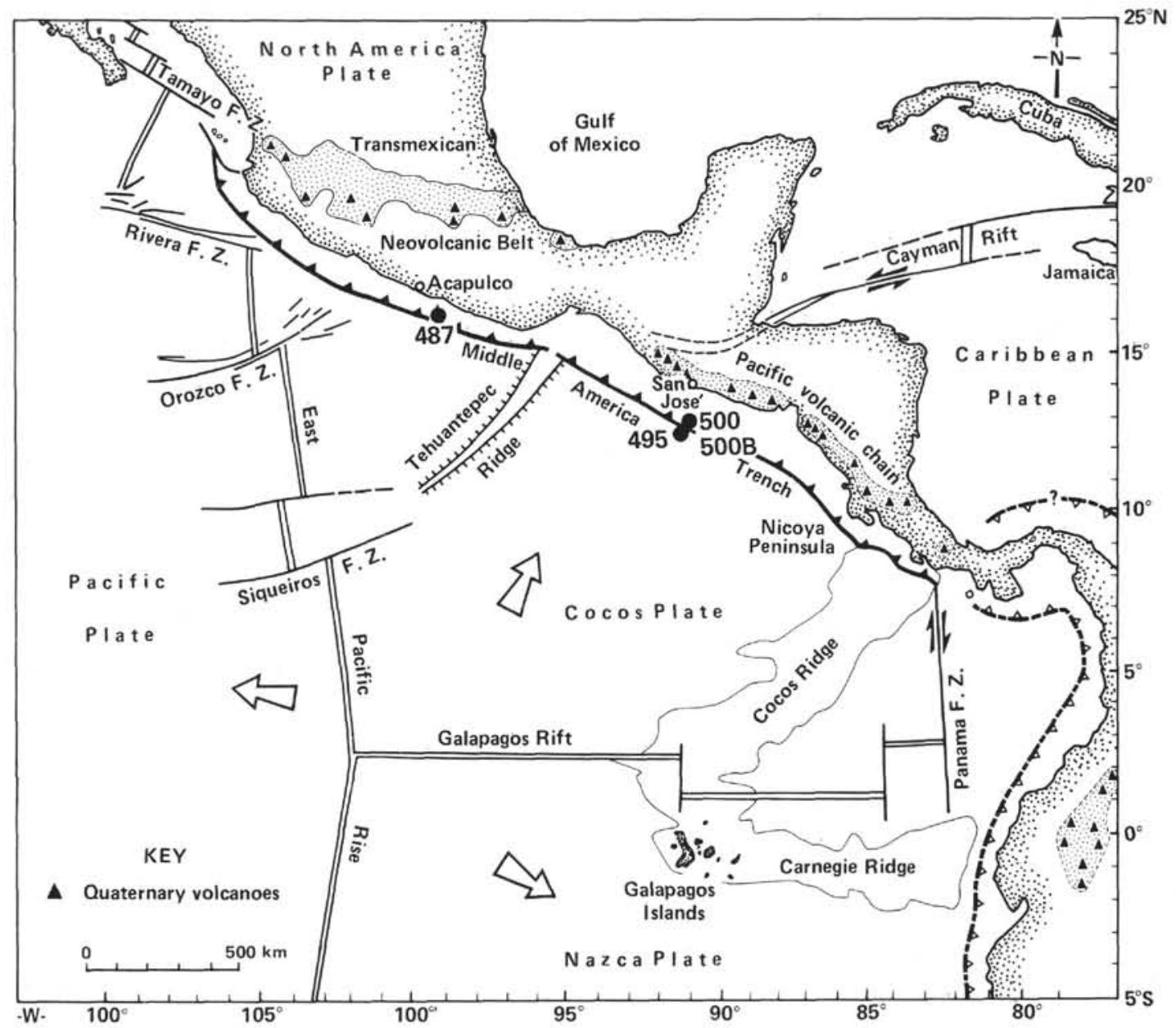

Figure 1. Location map of holes from which basalts were recovered on Legs 66 and 67.

Table 1. Modal composition of olivine-plagioclase phyric and plagioclase phyric basalts (vol. \%).

\begin{tabular}{|c|c|c|c|c|c|c|}
\hline \multirow[b]{2}{*}{ Sample $^{\mathrm{a}}$} & \multirow{2}{*}{$\begin{array}{l}\text { Sub-bottom } \\
\text { Depth } \\
\text { (m) }\end{array}$} & \multicolumn{2}{|c|}{ Phenocrysts } & \multicolumn{3}{|c|}{ Groundmass of the Rock } \\
\hline & & Plagioclase & Olivine & Plagioclase & Ore Mineral & Matrix \\
\hline \multicolumn{7}{|c|}{$\begin{array}{l}\text { Olivine-plagioclase } \\
\text { Phyric Basalts }\end{array}$} \\
\hline $\begin{array}{l}495-48-1,87 \\
495-48-1,83 \\
496-48-2,84 \\
495-48-4,93 \\
500-18-1,36 \\
500 \mathrm{~B}-3-1,64\end{array}$ & $\begin{array}{l}436.87 \\
437.83 \\
438.84 \\
441.93 \\
156.8 \\
124.6\end{array}$ & $\begin{array}{l}3.5 \\
3.1 \\
3.3 \\
1.6 \\
7.3 \\
1.1\end{array}$ & $\begin{array}{l}+b \\
+ \\
0.5 \\
2.3 \\
+ \\
+\end{array}$ & $\begin{array}{c}29.3 \\
29.9 \\
40.3 \\
43.7 \\
+ \\
+ \\
21.1\end{array}$ & $\begin{array}{c}2.0 \\
\text { In matrix } \\
4.1 \\
7.3 \\
4 \\
9.0\end{array}$ & $\begin{array}{l}65.2 \\
67.0 \\
51.8 \\
45.1 \\
92.7 \\
68.8\end{array}$ \\
\hline \multicolumn{7}{|l|}{$\begin{array}{l}\text { Plagioclase } \\
\text { Phyric Basalts }\end{array}$} \\
\hline $\begin{array}{l}500-19-1,9 \\
500-19-1,52\end{array}$ & $\begin{array}{l}156.5 \\
156.8\end{array}$ & $\begin{array}{l}7.4 \\
1.3\end{array}$ & $z^{6}$ & $\begin{array}{l}23.8 \\
30.4\end{array}$ & In matrix & $\begin{array}{l}68.8 \\
61.3\end{array}$ \\
\hline
\end{tabular}

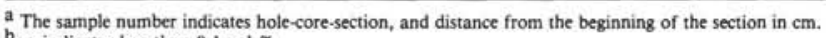
+ indicates less than 0.1 vol. \%

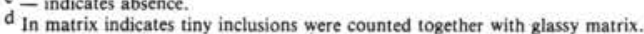

the groundmass of basalts correlates directly with the degree of their crystallization.

Clinopyroxenes are present in the groundmass of basalts in the form of incipient crystals and their aggregates (augite, $\mathrm{En}_{33-15} \mathrm{Wo}_{42-32} \mathrm{Fs}_{25-54}$ ) (Table 5).

Ore minerals of olivine-plagioclase phyric basalts are represented by titanomagnetite and ilmenite (Table 6), which are more abundant in better-crystallized rocks.

\section{Plagioclase Phyric Basalts}

Plagioclase phyric basalts underlie olivine-plagioclase phyric basalts in Hole 500. Absence of olivine phenocrysts distinguishes the uppermost rocks. (Table 1).

The composition of rock-forming minerals in olivineplagioclase phyric basalts and in plagioclase phyric basalts is, in general, similar (Tables 2,3 , and 5), with a somewhat higher content of $\mathrm{CaO}$ in plagioclases and clinopyroxenes as well as of $\mathrm{Al}_{2} \mathrm{O}_{3}$ in spinel in plagioclase phyric basalts. The crystallization temperature of plagioclase phenocrysts in Sample 500-19-1, $9 \mathrm{~cm}$ is 1235 to $1245^{\circ} \mathrm{C}$ (analysis by I. P. Solovova), which is practically the same as the crystallization temperature of plagioclase phenocrysts in olivine-plagioclase phyric basalts. The lower ratio $\mathrm{Cr} / \mathrm{Cr}+\mathrm{Al}=0.40$ in spinel from plagioclase phyric basalts possibly indicates crystallization at a lower temperature than crystallization of spinel in olivine-plagioclase phyric basalts.

\section{PETROCHEMISTRY AND GEOCHEMISTRY OF BASALTS}

The relative abundances of $\mathrm{SiO}_{2}$ and $\mathrm{K}_{2} \mathrm{O}+\mathrm{Na}_{2} \mathrm{O}$ indicate that basalts of the Middle America Trench (Guatemala transect) belong to derivatives of tholeiitic basaltic magma. 
Table 2. Composition of plagioclase in olivine-plagioclase phyric and plagioclase phyric basalts (wt. \%).

\begin{tabular}{|c|c|c|c|c|c|c|}
\hline \multirow[b]{3}{*}{ Components } & \multicolumn{4}{|c|}{$\begin{array}{c}\text { Olivine-plagio- } \\
\text { clase Phyric } \\
\text { Basalts }\end{array}$} & \multicolumn{2}{|c|}{$\begin{array}{l}\text { Plagioclase Phyric } \\
\text { Basalts }\end{array}$} \\
\hline & \multicolumn{2}{|c|}{ Phenocrysts } & \multicolumn{2}{|c|}{ Microlites } & \multirow[b]{2}{*}{ Phenocrysts } & \multirow[b]{2}{*}{ Microlites } \\
\hline & 1 & 2 & 1 & 2 & & \\
\hline $\mathrm{SiO}_{2}$ & 50.1 & 49.1 & 54.5 & 51.5 & 50.3 & 51.8 \\
\hline $\mathrm{TiO}_{2}$ & 0.06 & 0.04 & 0.23 & 0.33 & - & 0.21 \\
\hline $\mathrm{Al}_{2} \mathrm{O}_{3}$ & 31.3 & 31.0 & 26.1 & 27.2 & 31.7 & 27.4 \\
\hline $\mathrm{FeO}$ & 0.71 & 0.55 & 1.4 & 1.4 & 0.49 & 1.4 \\
\hline $\mathrm{MgO}$ & 0.5 & 0.1 & 0.76 & 0.53 & - & 0.55 \\
\hline $\mathrm{CaO}$ & 16.5 & 16.9 & 13.4 & 14.2 & 17.7 & 14.4 \\
\hline $\mathrm{Na}_{2} \mathrm{O}$ & 2.5 & 2.3 & 3.7 & 2.7 & 1.5 & 3.2 \\
\hline $\mathrm{K}_{2} \mathrm{O}$ & 0.0 & 0.02 & 0.04 & 0.21 & 0.02 & 0.09 \\
\hline \multicolumn{7}{|c|}{ Cations on 8 oxygens } \\
\hline $\mathrm{Si}$ & 2.264 & 2.257 & 2.481 & 2.403 & 2.267 & 2.397 \\
\hline $\mathrm{Ti}$ & 0.002 & 0.001 & 0.008 & 0.011 & - & 0.007 \\
\hline $\mathrm{Al}$ & 1.666 & 1.679 & 1.400 & 1.495 & 1.684 & 1.494 \\
\hline $\mathrm{Fe}$ & 0.027 & 0.021 & 0.053 & 0.055 & 0.018 & 0.054 \\
\hline $\mathrm{Mg}$. & 0.034 & 0.007 & 0.051 & 0.037 & - & 0.038 \\
\hline $\mathrm{Ca}$ & 0.798 & 0.832 & 0.653 & 0.709 & 0.855 & 0.714 \\
\hline $\mathrm{Na}$ & 0.219 & 0.205 & 0.326 & 0.244 & 0.131 & 0.287 \\
\hline K & 0.000 & 0.001 & 0.002 & 0.012 & 0.001 & 0.005 \\
\hline$\% \mathrm{Ab}$ & 20.3 & 19.3 & 30.2 & 24.2 & 13.1 & 26.6 \\
\hline$\%$ An & 79.7 & 80.7 & 69.8 & 75.8 & 86.9 & 73.4 \\
\hline Name & \multicolumn{2}{|c|}{ Bytownite } & \multicolumn{2}{|c|}{$\begin{array}{l}\text { Labradorite- } \\
\text { Bytownite }\end{array}$} & Bytownite & Bytownite \\
\hline
\end{tabular}

$\mathrm{a}_{1}=$ Sample $495-48-4,93 \mathrm{~cm}$ from beginning of section. 2 = Sample 500-18-1, $36 \mathrm{~cm}$ from beginning of section.

b Sample 500-19-1, $9 \mathrm{~cm}$ from beginning of section.

Table 3. Composition of spinel in olivine-plagioclase phyric and plagioclase phyric basalts (wt, \%).

\begin{tabular}{lcc}
\hline Components & $\begin{array}{c}\text { Olivine-plagioclase } \\
\text { Phyric Basalts } \\
\text { (Sample } 495-48-4,93 \mathrm{~cm} \text { ) }\end{array}$ & $\begin{array}{c}\text { Plagioclase Phyric } \\
\text { Basalts }\end{array}$ \\
(Sample 500-19-1, $9 \mathrm{~cm}$ ) \\
$\mathrm{SiO}_{2}$ & 4.1 & 4.5 \\
$\mathrm{TiO}_{2}$ & 0.91 & 0.36 \\
$\mathrm{Al}_{2} \mathrm{O}_{3}$ & 25.0 & 31.5 \\
$\mathrm{FeO}$ & 20.5 & 15.2 \\
$\mathrm{MnO}$ & 0.35 & 0.19 \\
$\mathrm{MgO}$ & 13.0 & 14.9 \\
$\mathrm{CaO}$ & 0.81 & 1.6 \\
$\mathrm{NiO}$ & - & 0.12 \\
$\mathrm{Cr} 2 \mathrm{O}_{3}$ & 36.0 & 31.7 \\
& $\mathrm{Cations}$ on 4 oxygens & \\
$\mathrm{Si}$ & 0.122 & 0.129 \\
$\mathrm{Ti}$ & 0.020 & 0.008 \\
$\mathrm{Al}$ & 0.878 & 1.063 \\
$\mathrm{Fe}$ & 0.510 & 0.364 \\
$\mathrm{Mn}$ & 0.009 & 0.005 \\
$\mathrm{Mg}$ & 0.577 & 0.636 \\
$\mathrm{Ca}$ & 0.026 & 0.049 \\
$\mathrm{Ni}$ & - & 0.003 \\
$\mathrm{Cr}$ & 0.848 & 0.717 \\
$\mathrm{Cr} / \mathrm{Cr}+\mathrm{Al}$ & 0.49 & 0.40 \\
$\mathrm{Fe} / \mathrm{Fe}+\mathrm{Mg}$ & 0.469 & 0.364 \\
\hline
\end{tabular}

Olivine-plagioclase phyric and plagioclase phyric basalts that are distinguished by petrographical features also have different chemical compositions (Table 7). The difference in content of $\mathrm{Al}_{2} \mathrm{O}_{3}$ is the most obvious and constant. All the plagioclase phyric basalts are distinct from the olivine-plagioclase phyric basalts, as
Table 4. Composition of olivine in olivine-plagioclase phyric basalts (wt.\%).

\begin{tabular}{lcc} 
Components & Sample $495-48-4,93 \mathrm{~cm}$ & Sample $500-18-1,36 \mathrm{~cm}$ \\
\hline $\mathrm{SiO}_{2}$ & 40.7 & 41.5 \\
$\mathrm{Al}_{2} \mathrm{O}_{3}$ & 0.4 & $-\overline{1}$ \\
$\mathrm{FeO}$ & 14.3 & 0.16 \\
$\mathrm{MnO}$ & 0.25 & 47.3 \\
$\mathrm{MgO}$ & 45.9 & 0.63 \\
$\mathrm{CaO}$ & 0.55 & 0.29 \\
$\mathrm{NiO}$ & 0.17 & \\
& Cations on 4 oxygens & \\
$\mathrm{Si}$ & 0.997 & 1.014 \\
$\mathrm{Al}$ & 0.011 & - \\
$\mathrm{Fe}$ & 0.292 & 0.226 \\
$\mathrm{Mn}$ & 0.005 & 0.003 \\
$\mathrm{Mg}$ & 1.674 & 1.721 \\
$\mathrm{Ca}$ & 0.014 & 0.016 \\
$\mathrm{Ni}$ & 0.006 & 0.06 \\
$\%$ Fo & 85.1 & 88.4 \\
$\mathrm{Name}$ & Chrysolite & Chrysolite \\
\hline
\end{tabular}

Table 5. Composition of clinopyroxene in olivine-plagioclase phyric and plagioclase phyric basalts (wt.\%).

\begin{tabular}{|c|c|c|c|}
\hline \multirow[b]{2}{*}{ Components } & \multicolumn{2}{|c|}{ Olivine-plagioclase Phyric Basalts } & \multirow{2}{*}{$\begin{array}{c}\begin{array}{c}\text { Plagioclase } \\
\text { Phyric Basalts }\end{array} \\
\text { Sample } \\
500-19-1,9 \mathrm{~cm}\end{array}$} \\
\hline & $\begin{array}{c}\text { Sample } \\
495-48-4,93 \mathrm{~cm}\end{array}$ & $\begin{array}{c}\text { Sample } \\
500-18-1,36 \mathrm{~cm}\end{array}$ & \\
\hline $\mathrm{SiO}_{2}$ & 51.7 & 51.7 & 60.2 \\
\hline $\mathrm{TiO}_{2}$ & 1.5 & 0.48 & 1.3 \\
\hline $\mathrm{Al}_{2} \mathrm{O}_{3}$ & 3.6 & 16.8 & 15.0 \\
\hline $\mathrm{FeO}$ & 9.8 & 8.5 & 7.4 \\
\hline $\mathrm{MnO}$ & 0.21 & 0.08 & 0.04 \\
\hline $\mathrm{MgO}$ & 11.8 & 5.0 & 2.9 \\
\hline $\mathrm{CaO}$ & 19.2 & 9.1 & 12.1 \\
\hline $\mathrm{Na}_{2} \mathrm{O}$ & 0.98 & 3.0 & 1.6 \\
\hline $\mathrm{K}_{2} \mathrm{O}$ & - & 0.49 & 0.57 \\
\hline \multicolumn{4}{|c|}{ Cations on 6 oxygens } \\
\hline $\mathrm{Si}$ & 1.945 & 1.922 & 2.072 \\
\hline $\mathrm{Ti}$ & 0.042 & 0.013 & 0.034 \\
\hline $\mathrm{Al}$ & 0.160 & 0.736 & 0.609 \\
\hline $\mathrm{Fe}$ & 0.308 & 0.264 & 0.213 \\
\hline Mn & 0.007 & 0.002 & 0.001 \\
\hline $\mathrm{Mg}$ & 0.661 & 0.279 & 0.149 \\
\hline $\mathrm{Ca}$ & 0.774 & 0.362 & 0.446 \\
\hline $\mathrm{Na}$ & 0.071 & 0.216 & 0.107 \\
\hline $\mathrm{K}$ & - & 0.023 & 0.025 \\
\hline$\%$ En & 33.0 & 14.7 & 15.3 \\
\hline$\%$ Wo & 42.2 & 31.7 & 59.3 \\
\hline$\%$ Fs & 24.8 & 53.6 & 25.4 \\
\hline Name & Augite & Augite & Augite \\
\hline
\end{tabular}

shown by an $\mathrm{Al}_{2} \mathrm{O}_{3} / \mathrm{Fe}_{2} \mathrm{O}_{3}+\mathrm{FeO}+\mathrm{MgO}$ ratio of more than 1 .

Normal and high-alumina basalts can be connected with oceanic as well as with island-arc magmatism, therefore to determine formational type and petrochemical peculiarities of Middle America Trench basalts, it is necessary to compare them with the same kind of basalts from oceanic and island-arc environments.

It should be remembered that according to the concepts of plate tectonics (Le Pichon et al., 1973), basalts of the outer zones of deep-sea trenches belong to a for- 
Table 6. Composition of ore minerals in olivineplagioclase phyric basalts (wt.\%).

\begin{tabular}{lccrc}
\hline & \multicolumn{4}{c}{ Olivine-plagioclase Phyric Basalts } \\
\cline { 2 - 5 } Components & \multicolumn{4}{c}{ Sample $495-48-4,93 \mathrm{~cm}$ ) } \\
\hline $\mathrm{SiO}_{2}$ & 7.9 & 7.8 & 8.2 & 6.7 \\
$\mathrm{TiO}_{2}$ & 17.2 & 18.3 & 21.5 & 42.6 \\
$\mathrm{Al}_{2} \mathrm{O}_{3}$ & 4.8 & 4.4 & 4.5 & 3.1 \\
$\mathrm{FeO}$ & 64.3 & 63.0 & 62.4 & 44.2 \\
$\mathrm{MnO}$ & 0.67 & 0.61 & 0.69 & 0.64 \\
$\mathrm{MgO}$ & 2.9 & 1.9 & 0.93 & 1.6 \\
$\mathrm{CaO}$ & 1.2 & 1.6 & 1.1 & 1.2 \\
Name & \multicolumn{5}{c}{ Titanomagnetite } & Ilmenite \\
\hline
\end{tabular}

mational type-oceanic spreading zone basalts. These basalts were formed in axial zones of mid-oceanic ridges and then mechanically transported to convergent margins of lithospheric plates, where oceanic crust began to be subducted under island arcs and continents.

According to this concept, deep-sea trenches are considered amagmatic morphostructures, behind which, at a distance controlled by the inclination of Benioff zone, volcanoes of island arcs and marginal continental cordilleras occur.

Other scientists who have analyzed oceanic and continental magmatism from the standpoint of fixism (a concept based on the predominance of vertical over horizontal tectonic movements) also believe that deep-sea trenches mark a boundary between oceanic and continental (island-arc) crust, where there "must be discontinuity of all material and geophysical parameters" (Lutz, 1980).

In the last few years, discoveries have been made of volcanic vents on marginal swells and oceanic slopes of deep-sea trenches (Avdeiko et al., 1980) and of basalts on the oceanic slope of the Yap Trench that are essentially younger than those of adjacent areas of the
Pacific floor (Sharaskin et al., 1980). These discoveries evidently indicate relatively recent volcanism in the outer zone of deep-sea trenches, about which little more than nothing is known.

The geodynamic regime in regions of magmatic activity should leave a mark on the composition of igneous rock associations. Deep-sea trenches represent morphostructural zones where regimes of spreading, typical of an oceanic environment, are perhaps replaced by predominantly pressure regimes of destructive plate boundaries. The transitional tectonic position of deep-sea trenches between areas with oceanic magmatism and regions with island-arc-type magmatism could imprint the composition of trench-zone basalts and bring about their intermediate nature between abyssal and island-arc tholeiites.

The petrochemistry and geochemistry of the Middle America Trench (Guatemala transect) basalts confirm this hypothesis. As mentioned earlier, the outer slope of the Middle America Trench and adjacent oceanic floor belong to the Cocos Plate. Inside this fragment of the Pacific lithosphere basaltic magmatism is recognized in the axial zone of the East Pacific Rise, in the Galapagos Spreading Center, and, possibly, in such transform faults as Siqueiros. Basic tholeiitic rocks that occur there are represented by normal, high alumina, and ferrobasalts (Table 8). If Middle America Trench basalts had been formed together with other basalts of the Cocos Plate in spreading or fault zones of this part of the Pacific, their petrographic, petrochemical, and geochemical features should be the same (Dmitriev, 1980).

Middle America Trench basalts have been compared with island-arc-type basalts, such as Cenozoic basalts of the Central America and South America Cordillera, the formation of which is connected with processes in the zone of convergence of the Cocos, Nazca, Caribbean, and American lithospheric plates (Pichler and Weyl,

Table 7. Chemical composition of olivine-plagioclase phyric and plagioclase phyric basalts (wt.\%).

\begin{tabular}{|c|c|c|c|c|c|c|c|c|}
\hline \multirow[b]{2}{*}{ Components } & \multicolumn{5}{|c|}{ Olivine-plagioclase Phyric Basalts } & \multicolumn{3}{|c|}{ Plagioclase Phyric Basalts } \\
\hline & 1 & 2 & 3 & 4 & 5 & 6 & 7 & 8 \\
\hline $\mathrm{SiO}_{2}$ & 45.80 & 49.20 & 48.20 & 50.10 & 48.33 & 47.50 & 48.0 & 47.75 \\
\hline $\mathrm{TiO}_{2}$ & 1.47 & 1.51 & 1.81 & 1.18 & 1.49 & 1.27 & 1.74 & 1.51 \\
\hline $\mathrm{Al}_{2} \mathrm{O}_{3}$ & 15.15 & 15.60 & 16.80 & 15.30 & 15.71 & 20.55 & 17.55 & 19.05 \\
\hline $\mathrm{Fe}_{2} \mathrm{O}_{3}$ & 6.03 & 2.72 & 3.61 & 2.06 & 3.61 & 6.47 & 3.60 & 5.04 \\
\hline $\mathrm{FeO}$ & 3.80 & 7.27 & 6.29 & 6.69 & 6.01 & 3.08 & 5.31 & 4.20 \\
\hline $\mathrm{MnO}$ & 0.21 & 0.16 & 0.12 & 0.17 & 0.17 & 0.07 & 0.12 & 0.10 \\
\hline $\mathrm{MgO}$ & 5.05 & 7.24 & 5.70 & 8.67 & 6.67 & 3.42 & 6.50 & 4.96 \\
\hline $\mathrm{CaO}$ & 13.94 & 11.58 & 11.07 & 11.16 & 11.94 & 11.17 & 11.18 & 11.18 \\
\hline $\mathrm{Na}_{2} \mathrm{O}$ & 3.02 & 2.98 & 3.01 & 2.31 & 2.33 & 2.90 & 2.88 & 2.89 \\
\hline $\mathrm{K}_{2}{ }^{\circ} \mathrm{O}$ & 0.32 & 0.075 & 0.63 & 0.053 & 0.27 & 0.72 & 0.42 & 0.57 \\
\hline $\mathrm{H}_{2} \mathrm{O}^{-}$ & 0.32 & 0.52 & 0.60 & - & 0.48 & 0.72 & 0.35 & 0.54 \\
\hline $\mathrm{H}_{2} \mathrm{O}^{+}$ & 2.08 & 1.08 & 1.71 & 1.95 & 1.71 & 1.68 & 2.03 & 1.86 \\
\hline $\mathrm{P}_{2} \mathrm{O}_{5}$ & 0.18 & 0.19 & 0.26 & 0.10 & 0.19 & 0.25 & 0.25 & 0.25 \\
\hline $\mathrm{CO}_{2}$ & 2.11 & n.d. & 0.42 & 0.24 & 0.69 & 0.18 & n.d. & 0.09 \\
\hline $\mathrm{s}$ & n.d. & 0.10 & 0.02 & 0.07 & 0.05 & 0.06 & 0.03 & 0.04 \\
\hline F & 0.04 & 0.03 & 0.04 & 0.04 & 0.04 & 0.04 & 0.04 & 0.03 \\
\hline $\mathrm{Cl}$ & 0.07 & 0.06 & 0.06 & 0.04 & 0.04 & 0.15 & 0.04 & 0.03 \\
\hline $\mathrm{Cr}_{2} \mathrm{O}_{3}$ & 0.05 & 0.05 & 0.03 & 0.06 & 0.05 & 0.09 & 0.05 & 0.07 \\
\hline $\mathrm{V}_{2} \mathrm{O}_{5}$ & 0.05 & 0.05 & 0.05 & 0.05 & 0.05 & 0.05 & 0.06 & 0.06 \\
\hline $\mathrm{Li}_{2} \mathrm{O}$ & 0.0050 & 0.0016 & 0.0017 & 0.0033 & 0.003 & 0.0011 & 0.0012 & 0.0012 \\
\hline $\mathrm{Rb}_{2} \mathrm{O}$ & 0.0009 & 0.0007 & 0.0018 & 0.0005 & 0.001 & 0.0010 & 0.0010 & 0.0010 \\
\hline $\mathrm{Cs}_{2} \mathrm{O}$ & 0.0021 & 0.0002 & 0.0002 & 0.0002 & 0.0008 & 0.0028 & 0.0002 & 0.0015 \\
\hline Total & 100.20 & 100.42 & 100.44 & 100.24 & 100.32 & 100.37 & 100.15 & 100.22 \\
\hline
\end{tabular}

Note: 1 = Sample $495-48-1,83 \mathrm{~cm}$ from beginning of section; 2 = Sample $495-48-4,93 \mathrm{~cm} ; 3=$ Sample $500-18-1,36 \mathrm{~cm} ; 4=$ Sample $500 \mathrm{~B}-3-1,64 \mathrm{~cm} ; 5$ = average from first four analyses. 6 = Sample $500-19-1$, $9 \mathrm{~cm} ; 7=$ Sample $500-19-1,52 \mathrm{~cm} ; 8$ = average from last two analyses; $n . d$. indicates that analysis for this component was not carried out; and - indicates that component is absent. 
Table 8. Chemical analyses of Pacific oceanic floor and island arc basalts (wt. \%).

\begin{tabular}{|c|c|c|c|c|c|c|c|c|c|}
\hline \multirow[b]{2}{*}{ Oxides } & \multicolumn{4}{|c|}{ Normal } & \multicolumn{2}{|c|}{ High-alumina } & \multicolumn{3}{|c|}{ Ferrobasalts } \\
\hline & 1 & 2 & 3 & 4 & 5 & 6 & 7 & 8 & 9 \\
\hline $\mathrm{SiO}_{2}$ & 49.5 & 49.78 & 49.52 & 48.4 & 47.67 & 49.2 & 49.3 & 49.28 & 49.45 \\
\hline $\mathrm{TiO}_{2}$ & 1.3 & 1.31 & 1.49 & 2.70 & 0.65 & 0.88 & 1.93 & 2.83 & 2.48 \\
\hline $\mathrm{Al}_{2} \mathrm{O}_{3}$ & 14.83 & 15.77 & 14.76 & 14.50 & 18.44 & 17.7 & 13.96 & 13.02 & 13.07 \\
\hline $\mathrm{Fe}_{2} \mathrm{O}_{3}$ & 2.17 & 9.70 & 10.39 & 11.80 & 2.08 & 1.09 & 12.85 & 2.92 & 14.45 \\
\hline $\mathrm{FeO}$ & 7.55 & n.d. & n.d. & n.d. & 5.83 & 6.75 & n.d. & 10.95 & n.d. \\
\hline $\mathrm{MnO}$ & 0.17 & 0.16 & n.d. & n.d. & 0.13 & 0.14 & 0.21 & 0.23 & n.d. \\
\hline $\mathrm{MgO}$ & 8.69 & 7.33 & 7.71 & 6.70 & 9.61 & 8.84 & 6.87 & 6.29 & 6.05 \\
\hline $\mathrm{CaO}$ & 12.25 & 12.33 & 11.81 & 11.50 & 12.64 & 12.57 & 10.28 & 10.07 & 10.33 \\
\hline $\mathrm{Na}_{2} \mathrm{O}$ & 3.00 & 2.62 & 2.46 & 2.70 & 2.12 & 2.47 & 2.70 & 3.29 & 2.95 \\
\hline $\mathrm{K}_{2} \mathrm{O}$ & 0.12 & 0.19 & 0.19 & 0.40 & 0.11 & 0.05 & 0.18 & 0.25 & 0.38 \\
\hline $\mathrm{H}_{2} \mathrm{O}^{+}$ & n.d. & n.d. & 1.24 & n.d. & 0.32 & n.d. & n.d. & n.d. & 1.40 \\
\hline $\mathrm{P}_{2} \mathrm{O}_{5}$ & 0.16 & 0.12 & 0.15 & n.d. & 0.07 & 0.10 & n.d. & 0.25 & 0.19 \\
\hline Total & 99.74 & 99.31 & 99.72 & 98.70 & 99.67 & 99.79 & 99.38 & 99.38 & 100.75 \\
\hline No. of analyses & 17 & 19 & 16 & 7 & 4 & 2 & 21 & 4 & 6 \\
\hline
\end{tabular}

Note: $1,6,7$ = Siqueiros Transform Fault (Batiza et al., 1977); 2, 5, 8 = Galapagos Spreading Center (Anderson et al., 1975, 1976: Dmitriev, in press; Engel and Engel, 1965: Rudnik, 1976); 3, 9 = East Pacific Rise (Dmitriev, 1980; Yeats et al., 1973); 4 = Galapagos Islands (McBirney and Williams, 1969); $\mathrm{n} . \mathrm{d} .=$ not determined.

1973; Stoiber and Carr, 1974). In Table 9 these basalts are also compared with those of Pacific island arcs representing different stages of evolution (Mariana, Tonga, New Hebrides, Aleutian, and Kamchatka-Kuril). To reveal and confirm typical features of deep-sea trench basalts, analyses of basalts from the Philippine and Yap trenches (outer slopes) were used along with analyses of Middle America Trench basalts (Table 10).

Petrochemical studies show that specific features of basalts erupted in different oceanic tectonic settings are most clearly expressed in concentrations and relations of such elements as $\mathrm{Fe}, \mathrm{Mg}, \mathrm{Al}, \mathrm{Ti}$, and the alkalies. Accordingly, to contrast and compare basalts of the Middle America Trench with basalts of other morphostructures of the Pacific, ratios such as $100 \times \mathrm{FeO}^{\prime} / \mathrm{FeO}^{\prime}$ $+\mathrm{MgO}\left(\mathrm{FeO}^{\prime}\right.$ is total $\mathrm{Fe}$ as $\left.\mathrm{FeO}\right), \mathrm{Al}_{2} \mathrm{O}_{3} / \mathrm{Fe}_{2} \mathrm{O}_{3}+$ $\mathrm{FeO}+\mathrm{MgO}, \mathrm{TiO}_{2} / \mathrm{Al}_{2} \mathrm{O}_{3}, \mathrm{~K}_{2} \mathrm{O} / \mathrm{K}_{2} \mathrm{O}+\mathrm{Na}_{2} \mathrm{O}$, and $\mathrm{K} / \mathrm{Rb}$ were used in this study. By these parameters, normal tholeiitic basalts of the Middle America Trench (Guatemala transect) resemble basalts of oceanic spreading zones, which, however, have essentially a higher $\mathrm{K} / \mathrm{Rb}$ ratio and a lower $\mathrm{Al}_{2} \mathrm{O}_{3} / \mathrm{Fe}_{2} \mathrm{O}_{3}+\mathrm{FeO}+\mathrm{MgO}$ ratio (Table 11). By the latter parameter, Middle America Trench basalts are correlated with basalts of the Central America Cordillera.
The correlation of Middle America Trench (Guatemala transect) high-alumina basalts with the same type basalts of other morphostructures of the Pacific (Table 12) reveals that by their petrochemical features these rocks more closely resemble high-alumina island-arc basalts. By the $\mathrm{K}_{2} \mathrm{O} / \mathrm{K}_{2} \mathrm{O}+\mathrm{Na}_{2} \mathrm{O}$ ratio, Middle America Trench high-alumina basalts closely resemble the highalumina basalts of the South America Cordillera and of such primitive island arcs as Tonga and Mariana.

The comparison of particular and especially average analyses of igneous rocks cannot provide a comprehensive notion of their genetic relations, because chemical peculiarities, which reflect the stage of the parental magma differentation, are not fully considered in such an approach. Therefore, to decide whether manifestations of magmatism of, say, this or that oceanic morphostructure resemble each other or not, it is more informative to compare the composition not of separate types of rocks that occur in these morphostructures but of series of these rocks, formed during the evolution of corresponding parental magmas.

The position of rocks in the sequence of differentiates of the tholeiitic basaltic magma can be determined quite reliably by the value of the $\mathrm{FeO}^{\prime} / \mathrm{FeO}^{\prime}+\mathrm{MgO}$ ratio, calculated on the basis of bulk chemical analyses of the rocks. Thus variations of concentrations of rockforming oxides in sequences of basaltic rocks with increasing values of the $\mathrm{FeO}^{\prime} / \mathrm{FeO}^{\prime}+\mathrm{MgO}$ ratio reflect basic regularities of evolution of these rock parental magmas. Uniformity or fluctuations in variation trends provide the possibility of speaking about unique or multiple parental magmas.

Let us analyze the position of Middle America Trench (Guatemala transect) basalts as well as basalts of other Pacific morphostructures on $\mathrm{TiO}_{2}-100 \times \mathrm{FeO}^{\prime} / \mathrm{FeO}^{\prime}+$ $\mathrm{MgO}, \mathrm{Al}_{2} \mathrm{O}_{3}-100 \times \mathrm{FeO}^{\prime} / \mathrm{FeO}^{\prime}+\mathrm{MgO}$, and $\mathrm{K}_{2} \mathrm{O}-\mathrm{K}_{2} \mathrm{O}$ $+\mathrm{Na}_{2} \mathrm{O}$ diagrams (Figs. 2-4).

The concentration of $\mathrm{TiO}_{2}$ is one of the most sensitive and reliable indicators of basaltic rock formational type (Chayes, 1964); indeed, on the $\mathrm{TiO}_{2}-100 \times \mathrm{FeO}^{\prime} /$ $\mathrm{FeO}^{\prime}+\mathrm{MgO}$ diagram (Fig. 2), tholeiitic basalts of the Galapagos Islands, the Siqueiros Transform Fault, and island arcs form variation trends disconnected in space. From the same diagram it is quite obvious that East

Table 9. Chemical analyses of basalts of Pacific island arcs (wt. \%).

\begin{tabular}{|c|c|c|c|c|c|c|c|c|c|c|}
\hline \multirow[b]{2}{*}{ Oxides } & \multicolumn{4}{|c|}{ Normal } & \multicolumn{5}{|c|}{ High-alumina } & \multirow{2}{*}{$\frac{\text { Ferrobasalts }}{10}$} \\
\hline & 1 & 2 & 3 & 4 & 5 & 6 & 7 & 8 & 9 & \\
\hline $\mathrm{SiO}_{2}$ & 50.1 & 49.69 & 52.06 & 48.79 & 49.19 & 50.94 & 51.92 & 50.57 & 51.52 & 51.2 \\
\hline $\mathrm{TiO}_{2}$ & 0.53 & 1.05 & 1.02 & 0.63 & 0.42 & 0.86 & 1.01 & 0.83 & 0.81 & 0.98 \\
\hline $\mathrm{Al}_{2} \mathrm{O}_{3}$ & 15.3 & 14.08 & 15.96 & 16.39 & 20.61 & 19.34 & 17.72 & 19.26 & 18.29 & 16.0 \\
\hline $\mathrm{Fe}_{2} \mathrm{O}_{3}$ & 2.83 & 4.83 & 5.00 & 1.74 & 2.93 & 1.58 & 3.79 & 4.29 & 4.19 & 4.2 \\
\hline $\mathrm{FeO}$ & 4.84 & 4.42 & 3.50 & 8.70 & 5.63 & 7.15 & 5.66 & 5.10 & 5.9 & 7.8 \\
\hline $\mathrm{MnO}$ & 0.14 & 0.21 & n.d. & 0.20 & - & 0.16 & 0.18 & 0.18 & 0.09 & 0.17 \\
\hline $\mathrm{MgO}$ & 9.24 & 9.99 & 8.13 & 8.63 & 5.93 & 5.94 & 5.71 & 5.08 & 4.3 & 5.1 \\
\hline $\mathrm{CaO}$ & 9.68 & 10.56 & 9.50 & 12.09 & 11.78 & 9.14 & 9.10 & 10.38 & 10.27 & 7.4 \\
\hline $\mathrm{Na}_{2} \mathrm{O}$ & 2.11 & 2.68 & 2.85 & 2.05 & 1.21 & 3.31 & 2.99 & 3.34 & 2.72 & 2.7 \\
\hline $\mathrm{K}_{2} \mathrm{O}$ & 0.49 & 0.96 & 1.62 & 0.68 & 0.24 & 0.55 & 1.02 & 1.15 & 0.67 & 0.75 \\
\hline $\mathrm{H}_{2}^{-} \mathrm{O}^{-}$ & 2.90 & - & 0.18 & - & - & 0.71 & - & - & 0.132 & 0.31 \\
\hline $\mathrm{H}_{2} \mathrm{O}^{+}$ & 1.68 & - & 0.32 & - & - & - & - & - & 0.14 & 0.37 \\
\hline $\mathrm{P}_{2} \mathrm{O}_{5}$ & 0.04 & 0.33 & n.d. & 0.15 & 0.01 & 0.22 & 0.32 & 0.22 & 0.10 & 0.19 \\
\hline Total & 99.88 & 98.80 & 100.14 & 99.99 & 97.95 & 99.9 & 99.42 & 100.4 & 99.12 & 97.17 \\
\hline No. of analyses & 2 & 22 & 1 & 1 & 1 & 1 & 131 & 1 & 8 & 4 \\
\hline
\end{tabular}

Note: 1, 9, 10 = Mariana (Larson, 1974; Stark, 1963); 2, 7 = Kamchatka (Leonova et al., 1978); 3 = Central America Cordillera, volcano Irazu (Robin and Tournon, 1978); $4=$ New Hebrides (Gorton, 1977); $5=$ Tonga (Bryan et al.. 1972); 6 = South America Cordillera, Casablanca volcano (Lopes-Escobar et al. 1977); and $8=$ Aleutian (Marsh, 1976); $n . d .=$ not determined; $-=$ absent. 
Table 10. Chemical analyses of deep-sea trench (outer slope) basalts of the Pacific (wt.\%).

\begin{tabular}{|c|c|c|c|c|c|}
\hline \multirow[b]{2}{*}{ Oxides } & \multicolumn{3}{|c|}{ Normal } & \multicolumn{2}{|c|}{ High-alumina } \\
\hline & $\begin{array}{l}\text { Yap (Sharaskin } \\
\text { et al., 1980) }\end{array}$ & $\begin{array}{l}\text { Middle America } \\
\text { Trench (South } \\
\text { Mexico transect) } \\
\text { (Dmitriev, } \\
\text { in press) }\end{array}$ & $\begin{array}{l}\text { Philippine Trench } \\
\text { (Dmitriev, 1979) }\end{array}$ & $\begin{array}{l}\text { Middle America } \\
\text { Trench (South } \\
\text { Mexico transect) } \\
\text { (Dmitriev, } \\
\text { in press) }\end{array}$ & $\begin{array}{l}\text { Yap (Sharaskin } \\
\text { et al., 1980). }\end{array}$ \\
\hline $\mathrm{SiO}_{2}$ & 50.47 & 48.0 & 46.92 & 47.7 & 48.1 \\
\hline $\mathrm{TiO}_{2}^{2}$ & 0.98 & 0.88 & 1.29 & 0.88 & 0.98 \\
\hline $\mathrm{Al}_{2} \mathrm{O}_{3}$ & 15.79 & 16.49 & 15.89 & 17.6 & 17.57 \\
\hline $\mathrm{Fe}_{2} \mathrm{O}_{3}$ & 4.15 & 3.19 & 6.56 & 3.24 & 6.35 \\
\hline $\mathrm{FeO}$ & 5.36 & 5.69 & 4.48 & 5.64 & 4.59 \\
\hline $\mathrm{MnO}$ & 0.15 & 0.25 & 0.18 & 0.11 & 0.07 \\
\hline $\mathrm{MgO}$ & 7.42 & 8.30 & 6.75 & 8.19 & 4.92 \\
\hline $\mathrm{CaO}$ & 12.01 & 13.40 & 12.34 & 12.91 & 11.95 \\
\hline $\mathrm{Na}_{2} \mathrm{O}$ & 2.60 & 2.03 & 2.23 & 1.98 & 2.85 \\
\hline $\mathrm{K}_{2} \mathrm{O}$ & 0.12 & 0.14 & 0.32 & 0.10 & 0.20 \\
\hline $\mathrm{H}_{2} \mathrm{O}^{-}$ & n.d. & 0.48 & 0.64 & 0.14 & n.d. \\
\hline $\mathrm{H}_{2} \mathrm{O}^{+}$ & 0.61 & 1.38 & 1.68 & 1.37 & 1.61 \\
\hline $\mathrm{P}_{2} \mathrm{O}_{5}$ & 0.08 & 0.04 & 0.12 & 0.04 & 0.23 \\
\hline $\mathrm{CO}_{2}$ & 0.19 & 0.01 & 0.76 & 0.28 & 0.28 \\
\hline Total & 99.93 & 100.28 & 100.16 & 100.18 & 99.70 \\
\hline No. of Analyses & 6 & 4 & 1 & 2 & 2 \\
\hline
\end{tabular}

Table 11. Some petrochemical and geochemical parameters of normal tholeitic basalts of Pacific morphostructures.

\begin{tabular}{|c|c|c|c|c|c|c|c|c|c|c|c|c|c|c|c|c|}
\hline & \multicolumn{8}{|c|}{ Deep-sea Trenches } & \multicolumn{3}{|c|}{ Oceanic Floor } & \multicolumn{4}{|c|}{ Island Ares } & \multirow{2}{*}{$\frac{\text { Uceanic Islands }}{16}$} \\
\hline & 1 & 2. & 3 & 4 & 5 & 6 & 7 & 8 & 9 & 10 & 11 & 12 & 13 & 14 & 15 & \\
\hline $100 \times \mathrm{FeO}^{\prime} / \mathrm{FeO}^{\prime}+\mathrm{MgO}$ & 49.6 & 57.3 & 62.6 & 64.6 & 58.1 & 50.8 & 55.07 & 60.6 & 52.1 & 57.0 & 60.0 & 44.4 & 46.7 & 49.6 & 54.3 & 61.3 \\
\hline $\mathrm{Al}_{2} \mathrm{O}_{3} / \mathrm{Fe}_{2} \mathrm{O}_{3}+\mathrm{FeO}+\mathrm{MgO}_{8}$ & 0.9 & 0.9 & 1.0 & 1.0 & 1.0 & 1.0 & 0.9 & 0.9 & 0.8 & 0.9 & 0.8 & 0.9 & 0.7 & 1.0 & 0.9 & 0.8 \\
\hline $\mathrm{TiO}_{2} / \mathrm{Al}_{2} \mathrm{O}_{3}$ & 0.08 & 0.10 & 0.10 & 0.10 & 0.09 & 0.05 & 0.06 & 0.08 & 0.09 & 0.08 & 0.10 & 0.03 & 0.07 & 0.06 & 0.04 & 0.18 \\
\hline $\mathrm{K}_{2} \mathrm{O} / \mathrm{K}_{2} \mathrm{O}+\mathrm{Na}_{2} \mathrm{O}$ & 0.02 & 0.02 & 0.17 & 0.10 & 0.09 & 0.06 & 0.04 & 0.12 & 0.04 & 0.08 & 0.07 & 0.19 & 0.26 & 0.14 & 0.25 & 0.13 \\
\hline $\mathrm{K} / \mathrm{Rb}$ & 106.0 & 107.0 & 350.0 & 355.0 & 270.0 & 174.0 & 393.0 & - & $\begin{array}{l}\text { No data } \\
\text { available }\end{array}$ & & $\begin{array}{l}436 . \\
955\end{array}$ & $\begin{array}{l}\text { No data } \\
\text { available }\end{array}$ & 700 & $\begin{array}{l}\text { No data } \\
\text { available }\end{array}$ & & \\
\hline
\end{tabular}

Note: Middle America Trench, Guatemala transect: 1. Sample 500B-3-1, $64 \mathrm{~cm} ; 2$. Sample $495-48-4,93 \mathrm{~cm} ; 3$. Sample $500-18-1,36 \mathrm{~cm} ; 4$. Sample $495-48-1,83 \mathrm{~cm} ; 5$. average from first fou analyses; 6. South Mexico transect; 7. Yap Trench; 8. Philippine Trench; 9. Siqueiros Fault; 10. Galapagos Spreading Center; 11. East Pacific Rise; 12. Mariana island arc; 13. Kamchatka; 14. Central America Cordillera; 15. New Hebrides; 16. Galapagos Islands. Parameters were calculated on the basis of analyses in Tables 8,9 , and 10.

Table 12. Some petrochemical and geochemical parameters of high-alumina tholeitic basalts of Pacific morphostructures.

\begin{tabular}{|c|c|c|c|c|c|c|c|c|c|c|c|c|}
\hline & \multicolumn{5}{|c|}{ Deep-sea Trenches } & \multicolumn{2}{|c|}{$\begin{array}{c}\text { Oceanic } \\
\text { Floor }\end{array}$} & \multicolumn{5}{|c|}{ Island Arcs } \\
\hline & 1 & 2 & 3 & 4 & 5 & -6 & 7 & 8 & 9 & 10 & 11 & 12 \\
\hline $100 \times \mathrm{FeO}^{\prime} / \mathrm{FeO}^{\prime}+\mathrm{MgO}$ & 56.8 & 72.2 & 63.8 & 51.1 & 67.7 & 44.5 & 46.7 & 58.2 & 59.1 & 61.4 & 63.8 & 69.4 \\
\hline $\mathrm{Al}_{2} \mathrm{O}_{3} / \mathrm{Fe}_{2} \mathrm{O}_{3}+\mathrm{FeO}+\mathrm{MgO}$ & 1.1 & 1.6 & 1.3 & 1.0 & 1.1 & 1.1 & 1.1 & 1.4 & 1.3 & 1.2 & 1.3 & 1.3 \\
\hline $\mathrm{TiO}_{2} / \mathrm{Al}_{2} \mathrm{O}_{3}$ & 0.10 & 0.06 & 0.08 & 0.05 & 0.06 & 0.04 & 0.05 & 0.02 & 0.04 & 0.06 & 0.05 & 0.04 \\
\hline $\mathrm{K}_{2} \mathrm{O} / \mathrm{K}_{2} \mathrm{O}+\mathrm{Na}_{2} \mathrm{O}$ & 0.13 & 0.20 & 0.16 & 0.05 & 0.06 & 0.05 & 0.02 & 0.16 & 0.14 & 0.25 & 0.26 & 0.20 \\
\hline $\mathrm{K} / \mathrm{Rb}$ & 420.0 & 720.0 & 570.0 & 200.0 & 300.0 & \multicolumn{2}{|c|}{ No data available } & \multicolumn{5}{|c|}{ No data available } \\
\hline
\end{tabular}

Note: Middle America Trench, Guatemala transect: 1. Sample 500-19-1, $52 \mathrm{~cm} ; 2$. Sample 500-19-1, $9 \mathrm{~cm}$; 3, average from first two analyses. 4. South Mexico transect; 5. Yap Trench; 6. Galapagos Spreading Center; 7. Siqueiros Transform Fault; 8. Tonga; 9 . South America Cordillera: 10. Kamchatka: 11. Aleutian; 12. Mariana. Parameters arc calculated on the basis of analyses in Tables 8, 9, and 10.

Pacific Rise and Galapagos Spreading Center basalts that erupted under a similar geodynamic regime form practically the single evolutionary trend.

Basaltic series of oceanic morphostructures differ from those of island-arc basaltic series because of their essentially higher $\mathrm{TiO}_{2}$ concentrations and the primitive nature of their high-alumina basalts, which plot at the beginning of the evolutionary sequence $\left(100 \times \mathrm{FeO}^{\prime}\right)$ $\mathrm{FeO}^{\prime}+\mathrm{MgO}<47$ ); in contrast, island-arc series highalumina basalts belong to late differentiates $\left(100 \times \mathrm{FeO}^{\prime}\right)$ $\mathrm{FeO}^{\prime}+\mathrm{MgO}>58$ )

The distribution of Middle America Trench basalts as well as basalts of other deep-sea trenches on the $\mathrm{TiO}_{2}$ $100 \times \mathrm{FeO}^{\prime} / \mathrm{FeO}^{\prime}+\mathrm{MgO}$ diagram shows that significant amounts of these rocks are transitional between basalts of oceanic morphostructures and island-arc basalts. Half of the Middle America Trench (Guatemala transect) basalts, the average of high-alumina basalts of this transect, the average of normal and high-alumina basalts of the South Mexico transect of the Middle America Trench, and basalts of the Philippine and Yap trenches plot in the sector between the evolutionary trend of East Pacific Rise-Galapagos Spreading Center basalts and the evolutionary trend of Mariana island-arc basalts.

Different behavior of aluminium in the course of the evolution of oceanic and island-arc tholeitic basaltic magmas is clearly visible on the $\mathrm{Al}_{2} \mathrm{O}_{3}-100 \times \mathrm{FeO}^{\prime} / \mathrm{FeO}^{\prime}$ $+\mathrm{MgO}$ diagram (Fig. 3). In basaltic series of the Galapagos Spreading Center-East Pacific Rise, Siqueiros Transform Fault, and Galapagos islands, the content of $\mathrm{Al}_{2} \mathrm{O}_{3}$ decreases as the $100 \times \mathrm{FeO}^{\prime} / \mathrm{FeO}^{\prime}+\mathrm{MgO}$ ratio increases. In island-arc basaltic series (Mariana islands), however, aluminium does just the opposite.

In basalts of the Guatemala transect of the Middle America Trench one can see both tendencies of $\mathrm{Al}_{2} \mathrm{O}_{3}$. In basalts of Hole 495 drilled on the oceanic slope of the 


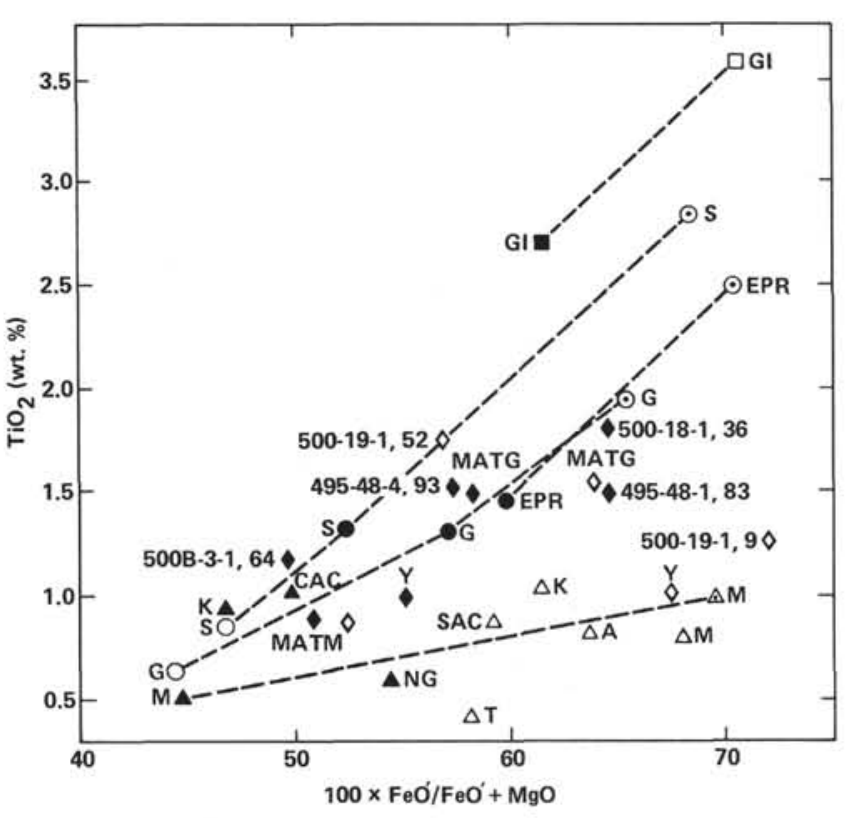

Figure 2. $\mathrm{TiO}_{2}-100 \times \mathrm{FeO}^{\prime} / \mathrm{FeO}^{\prime}+\mathrm{MgO}$ diagram (normal (๑), highalumina $(\odot)$, and ferrobasalts $(\odot)$ of spreading zones and transform faults [EPR = East Pacific Rise, $\mathrm{G}=$ Galapagos Spreading Center, $\mathrm{S}=$ Siqueiros Transform Fault]; normal ( $\mathbf{\square})$ and ferrobasalts $(\square)$ of oceanic islands [GI = Galapagos Islands]; normal $(\boldsymbol{\Delta})$, high-alumina $(\triangle)$, and ferrobasalts $(\Delta)$ of island arcs [A = Aleutian, $\mathrm{CAC}=$ Central America Cordillera, $\mathrm{K}=\mathrm{Kamchatka}$, $\mathbf{M}=$ Mariana, $\mathbf{N G}=$ New Hebrides, $\mathrm{SAC}=$ South America Cor dillera, $\mathrm{T}=\mathrm{T}$. $n g a]$; normal $(\diamond)$ and high-alumina basalts $(\diamond)$ of the deep-sea trench outer zones [MATG = Middle America Trench, Guatemala transect; MATM = Middle America Trench, South Mexico transect; $\mathrm{Ph}=$ Philippine, $\mathrm{Y}=\mathrm{Yap}]$; and --- evolutional trends of basalts).

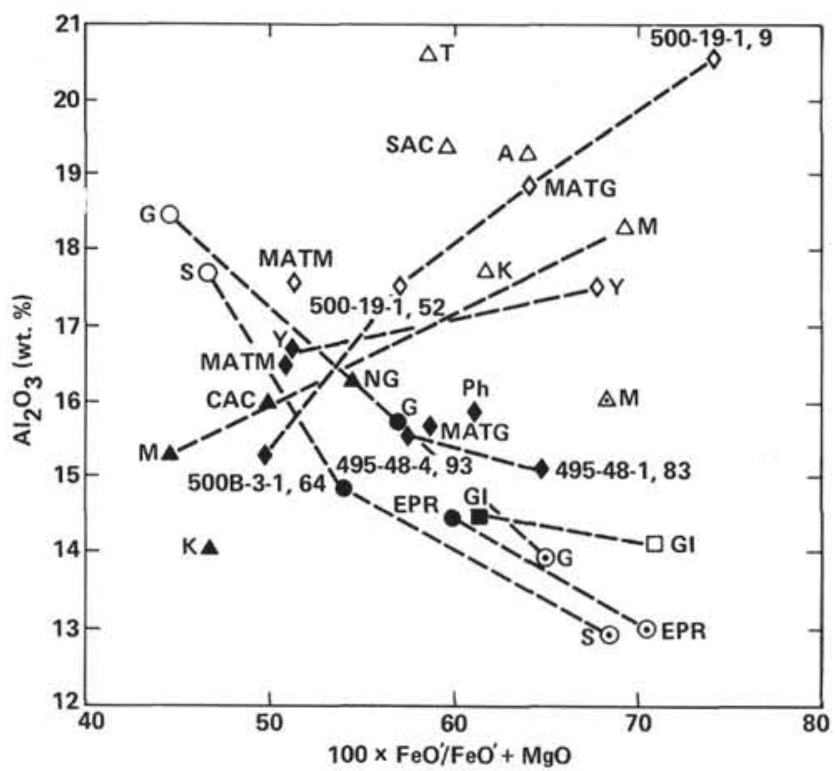

Figure 3. $\mathrm{Al}_{2} \mathrm{O}_{3}-100 \times \mathrm{FeO}^{\prime} / \mathrm{FeO}^{\prime}+\mathrm{MgO}$ diagram. (See Fig. 2 caption for an explanation of symbols and abbreviations.)

Trench $22 \mathrm{~km}$ from the axis, $\mathrm{Al}_{2} \mathrm{O}_{3}$ content decreases as the $100 \times \mathrm{FeO}^{\prime} / \mathrm{FeO}^{\prime}+\mathrm{MgO}$ ratio increases; the evolution of basaltic melts has the typical oceanic pattern. In contrast, in basalts of the Trench axis (Holes 500,
500B), concentrations of $\mathrm{Al}_{2} \mathrm{O}_{3}$ have a direct correlation with the value of the $100 \times \mathrm{FeO}^{\prime} / \mathrm{FeO}^{\prime}+\mathrm{MgO}$ ratio; that is, parental basaltic magma of these rocks evolves as in an island-arc environment. In basalts of the oceanic slope of the Yap Trench, correlation of $\mathrm{Al}_{2} \mathrm{O}_{3}$ and the $100 \times \mathrm{FeO}^{\prime} / \mathrm{FeO}^{\prime}+\mathrm{MgO}$ ratio is the same as in basalts of the Mariana island arc, although less clearly expressed.

Tholeiitic basalts of island arcs differ from oceanic basalts because of the greater role of potassium; this is quite obvious on the $\mathrm{K}_{2} \mathrm{O}-\mathrm{K}_{2} \mathrm{O}+\mathrm{Na}_{2} \mathrm{O}$ diagram (Fig. 4). Also, on this diagram as well as on the $\mathrm{TiO}_{2}-100$ $\times \mathrm{FeO}^{\prime} / \mathrm{FeO}^{\prime}+\mathrm{MgO}$ and $\mathrm{Al}_{2} \mathrm{O}_{3}-100 \times \mathrm{FeO}^{\prime} / \mathrm{FeO}^{\prime}+$ $\mathrm{MgO}$ diagrams one can see that among basalts of the Middle America Trench and other deep-sea trenches there are rocks with composition similar to that of typical oceanic tholeiitic basalts and rocks transitional to island-arc tholeiitic basalts. To this intermediate type of basalts, according to the $\mathrm{K}_{2} \mathrm{O} / \mathrm{K}_{2} \mathrm{O}+\mathrm{Na}_{2} \mathrm{O}$ ratio, belong basalts from Hole 500 and basalts of the Philippine Trench.

\section{CONCLUSION}

Analysis of petrochemical peculiarities of Middle America Trench (Guatemala transect) basalts reveals compositions typical of oceanic tholeiites and transitional to island-arc tholeiites. With respect to degree of differentiation, transitional-type basalts differ from comparable rocks of oceanic and island-arc series by intermediate values of $\mathrm{TiO}_{2}$ concentration and the $\mathrm{K}_{2} \mathrm{O} / \mathrm{K}_{2} \mathrm{O}$ $+\mathrm{Na}_{2} \mathrm{O}$ ratio. The common feature of transitional basalts and island-arc basalts is the advanced differentiation of high-alumina varieties in both types of rocks. Tholeiitic basalts of other deep-sea trenches, for example, Philippine and Yap trenches, have analogous chemical features.

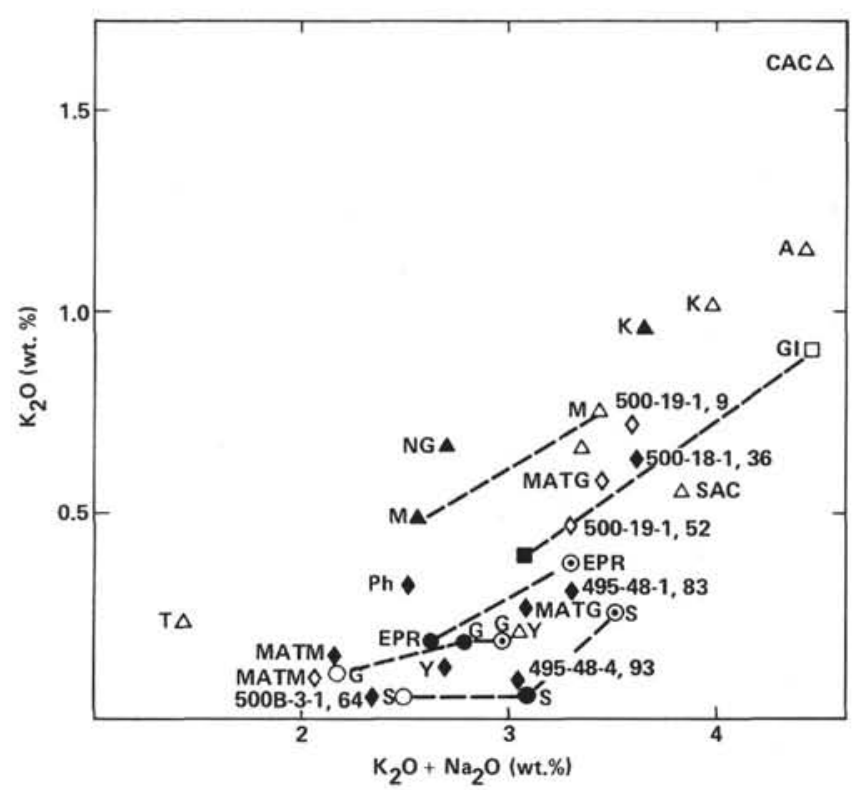

Figure 4. $\mathrm{K}_{2} \mathrm{O}-\mathrm{K}_{2} \mathrm{O}+\mathrm{Na}_{2} \mathrm{O}$ diagram. (See Fig. 2 caption for an explanation of symbols and abbreviations.) 
These petrochemical analyses, together with published data on the unexpectedly young age of some basalts from the seaward slopes of some deep-sea trenches, are perhaps evidences of local magmatism connected with the zone of convergence of oceanic and continental (island-arc) crust, where perhaps basalts transitional between oceanic and island-arc tholeiites were erupted.

\section{ACKNOWLEDGMENTS}

The author thanks the Leg 67 scientific party for providing basalt samples for this investigation. Bulk chemical analyses of these samples were carried out by Y. V. Dolinina and microprobe analyses of rockforming minerals by G. N. Muravizkaja in laboratories of the Institute of Geology of Ore Deposits, Petrography, Mineralogy, and Geochemistry of the U.S.S.R. Academy of Sciences. The author is also grateful to N. A. Bogadnov and S. A. Tsvetkov, who reviewed the manuscript.

\section{REFERENCES}

Anderson, R. N., Claque, D. A., Klitgord, K. D., Marshall, M., and Nishimori, R. K., 1975. Magnetic and petrologic variations along the Galapagos spreading center and their relation to the Galapagos melting anomaly. Geol. Soc. Am. Bull., 86:683-694.

Anderson, R. N., Schilling, J. G., and Vogt, P., 1976. Rare-earth, Fe and $\mathrm{Ti}$ variations along the Galapagos spreading center and their relationship to the Galapagos mantle plume. Nature, 261(5556): 108-113.

Avdeiko, G. P., Gorshkov, A. P., Sapozhnikov, E. A., Seliverstov, N. I., and Skripko, K. A., 1980. Underwater volcanoes of island arcs and marginal seas. In Bogatikov, O. A. (Ed.), Magmatic and Metamorphic Rocks of Oceanic Floor and Their Genesis: Moscow (Academy of Sciences of the U.S.S.R.), pp. 84-86. (In Russian)

Batiza, K., Rozendahl, B. R., and Fisher, R. L., 1977. Evolution of oceanic crust. Part III. Petrology and chemistry of basalts from the East Pacific Rise and Siqueiros Fracture Zone. J. Geophys. Res., 82:265-276.

Bryan, W. B., Stice, G. D., and Ewart, A., 1972. Geology, petrography and geochemistry of the volcanic island Tonga. J. Geophys. Res., 77:1556.

Chayes, F., 1964. A petrographic distinction between Cenozoic volcanics in and around the open oceans. J. Geophys. Res., 69(8): 1573-1588.

Dmitriev; Y. I., 1980. Basalts from the East Pacific Rise near $9^{\circ} \mathrm{N}$ drilled on Deep Sea Drilling Project, Leg 54 compared with marginal-basin and ocean-island basalts. In Rosendahl, B. R., Hekinian, R., et al., Init. Repts. DSDP, 54: Washington (U.S. Govt. Printing Office), 695-704.

, in press. Petrology and origin of basalts of the Middle America Trench (Southern Mexico Transect). In Watkins, F. S., Moore, C., Init. Repts. DSDP, 66: Washington (U.S. Govt. Printing Office).

Dmitriev, Y. I., Solovova, I. P., Dolinina, Y. V., and Muravitskaya, G. N., 1979. Petrology of the Philippine Sea basic rocks by Deep Sea Drilling data. Izv. Akad. Nauk USSR, Ser. Geol. 4:19-33. (In Russian)

Engel, C. G., and Engel, T. E., 1965. Composition of basalts dredged from seamounts of the west coast of Central America. Geological Survey Research, Chapter C. Geol. Surv. Prof. Pap., 525-C.
Fist, M. R., and Bence, A. E., 1980. Experimental crystallization of chrome spinel in FAMOUS Basalt 527-1-1. Earth Planet. Sci. Lett. $1: 111-123$.

Frolova, T. I., Rudnik, G. B., and Kashintsev, G. L., 1979. Some general regularities of oceanic magmatism and problems of magmatic rocks genesis. In Besrukov, P. L. (Ed.), Geology of the Ocean: Moscow (Nauka), p. 415. (In Russian)

Gorton, M. P., 1977. The geochemistry and origin of Quaternary volcanics in the New Hebrides. Geochim. Cosmochim. Acta, 41: $1257-1270$.

Larson, E. E., 1974. Major element petrochemistry of some extrusive rocks from the volcanically active Mariana Islands. Bull. Volcanol., 38(2):361-377.

Leonova, L. L., Popolitov, E. I., Volinets, O. N., Kirsanov, I. T., and Dubuk, Y. M., 1978. Types of Quaternary basalts of Kamchatka in connection with the problem of primary magmas. In Petrological Investigation of Island Arc Basic Rocks: Moscow (Nauka), pp. 157-176. (In Russian)

Le Pichon, X., Francheteau, J., and Bonnin, J., 1973. Plate Tectonics: Amsterdam-London-New York (Elsevier Scientific Publishing Company).

Lopes-Escobar, L., Frey, F. A., and Vergas, M., 1977. Andesites and high-alumina basalts from the Central South Chili High Andes. Geochemical bearing on their petrogenesis. Contrib. Mineral. Petrol., 63(3):203.

Lutz, B. G., 1980. Geochemistry of Oceanic and Continental Magmatism: Moscow (Nedra). (In Russian)

Mc Birney, A. R., and Williams, H., 1969. Geology and petrology of the Galapagos Islands. Geol. Soc. Am. Mem., N118.

Marsh, B. D., 1976. Some Aleutian andesites: their nature and source. J. Geol., 84:27-45.

Pichler, H., and Weyl, R., 1973. Petrochemical aspects of Central American magmatism. Geol. Rundsch., 62(2):357-396.

Robin, C., and Tournon, J., 1978. Spatial relation of andesitic and alkaline provinces in Mexico and Central America. Can. J. Earth Sci., 15(1):1633-1641.

Rudnik, G. B., 1976. Magmatic and metamorphic rocks of Hess depression. In Geological and Geophysical Investigations in Southeast Part of the Pacific: Moscow (Nauka), pp. 116-125. (In Russian)

Sharaskin, A. Ya., Zakariadze, G. S., Dmitriev, Y. I., Dobretsov, N. A., Levashov, G. B., Komatsu, M., Dietrich, V., and Oberhänsli, B., 1980. Petrology of volcanic rocks. In Peive, A. V. (Ed.), Geology of the Philippine Seafloor: Moscow (Nauka), pp. 106-149. (In Russian)

Stark, J. T., 1963. Petrology of the volcanic rocks of Guam. Geol. Surv. Prof. Pap., 403-C.

Stoiber, R. E., and Carr, M. J., 1974. Quaternary volcanic and tectonic segmentation of Central America. Bull. Volcanol., 37(3): 304-325.

von Huene, R., Aubouin, J., Azema, J., Blackinton, G., Carter, J. A., Coulbourn, W. T., Cowan, D. S., Curiale, J. A., Dengo, C. A., Faas, R. V., Harrison, W., Hess, R., Hussong, D. M., Ladd, J. W., Muzylev, N., Shiki, T., Thompson, P. R., and Westberg, J., 1980. Leg 67: The Deep Sea Drilling Project Middle America Trench transect of Guatemala. Geol. Soc. Am. Bull. Pt. I, 91 (7):421-432.

Yeats, R. S., Forbes, W. C., Heath, G. R., Scheidegger, K. F., 1973. Petrology and geochemistry of DSDP Leg 16 basalts, Eastern Equatorial Pacific. In van Andel, T. H., Heath, G. R., et al., Init. Repts. DSDP, 16: Washington (U.S. Govt. Printing Project), 617-640. 